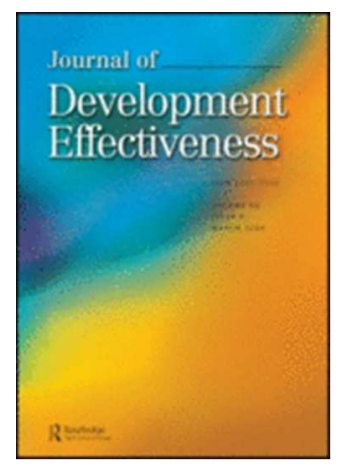

\title{
Economic Impacts of Conditional Cash Transfer Programmes: A systematic review and meta-analysis
}

\begin{tabular}{|r|l|}
\hline Journal: & Journal of Development Effectiveness \\
\hline Manuscript ID: & Draft \\
\hline Manuscript Type: & Papers in Special Issues \\
\hline Keywords: & $\begin{array}{l}\text { Conditional cash transfers, Impact evaluation, Systematic review, Meta- } \\
\text { analysis }\end{array}$ \\
\hline \multicolumn{2}{|c}{} \\
\hline
\end{tabular}

SCHOLARONE ${ }^{\text {m }}$

Manuscripts 
Economic Impacts of Conditional Cash Transfer Programmes: A systematic review and meta-analysis

We present results of a systematic review of evidence on the effects of conditional cash transfer (CCT) programmes on household economic outcomes. Out of 1,076 original articles found through electronic and handsearches, 46 high quality randomised and quasi-experimental impact evaluations were eligible for the review. We use statistical meta-analysis and analysis of programme mechanisms to explore heterogeneity in impacts between and within programmes. We conclude that, for households which benefited from those CCT programmes which have been rigorously evaluated, child labour decreased, household consumption and investment increased and consumption smoothing improved. In addition, there were mixed effects on adult labour supply in beneficiary households. Limited evidence has been collected on locality-wide impacts in beneficiary communities.

\section{Introduction}

The recent global economic crisis has given renewed emphasis to the importance of social protection as a 'smart investment' in an uncertain world (Lin and Phumaphi 2009, p. xi). Social protection programmes, including social transfers such as cash transfers, are estimated to reach over 150 million poor households in poor countries and benefit around half a billion people (Barrientos and Hulme 2008). Transfers conditional on work, as in public works programmes, have been used by governments to smooth consumption since before the Common Era (Dev, 
1995). Cash transfers conditional on prespecified investments in household human capital, are a relatively recent innovation which have spread rapidly. In 1997, there were just three programmes operating in Brazil, Mexico and Bangladesh. ${ }^{i}$ By 2008, there were over 30 programmes across Latin America and the Caribbean, Africa and Asia (Fizsbein and Schady 2009).

Tying cash transfers to human capital investments in children is argued to help break intergenerational poverty transmission. Systematic reviews of evidence on the impacts of cash transfer programmes indicate that they are effective in improving education attendance (Baird et al. 2012), immunisation coverage (Gaarder et al. 2010), health facility use (Lagarde et al. 2009) and child nutrition (Manley et al. 2012). Some reviews adopt a theory-based approach to analyse the mechanisms underlying these impacts (Leroy et al. 2009; Gaarder et al. 2010). In addition, conditional cash transfers (CCTs) may have direct economic consequences which could be of substantive importance to the household economy and beneficiary communities. Evidence for such impacts may help offset costs of financing social protection, easing their fiscal burden and increasing their appeal to policy makers.

This paper summarises findings of the first systematic review of the direct economic impacts of CCTs. ${ }^{\text {ii }}$ Section 2 presents the theoretical underpinnings and Section 3 describes the systematic review approach and included programmes. Section 4 presents evidence of CCT impacts on child labour allocation, and Section 5 adult labour. Evidence of impacts on expenditure patterns is presented in Section 6. Section 7 presents evidence on risk sharing and the local economy. The final section concludes. 


\section{Theory of change}

Cash transfers are likely to be too small, and the contributions of poor people to their country's per capita income too meagre, to generate direct impacts on macroeconomic growth or national poverty levels (Kabeer, 2009). However, Fizsbein and Schady (2009) identify three causal mechanisms through which conditional cash transfers may impact the household economy. These include an income effect relating to the transfer, which enables liquidity constrained poor households to undertake investments, and a substitution effect relating to the condition, which increases the opportunity costs of not taking children to health clinics and sending them to school. A third distribution effect may also operate, in which mothers are targeted as recipients of the transfer due to widespread belief (and emerging evidence e.g. Yoong et al., 2012) that mothers' preferences are more closely aligned with children's interests than the fathers', leading to an effect on intra household resource allocation and consequent expenditure and budgeting decisions. We refer to these as primary, intended, impacts (Figure 1).

However, there may also be secondary, perhaps unintended, impacts at the local level. If the income effect of the cash transfer is not exhausted by the additional expenditure on schooling, the substitution effect entails more than simply moving children from work or play into school. Some of the uses are likely to be economic in nature, including trading off work for leisure, meeting the costs of job search, including migration in search of work, or alternatively, reducing the need to migrate. Furthermore, the reallocation of children's time from work or play into school may also have ramifications for time use by other family members. For example, if children were previously in paid work, loss of their income would reduce the size of the income effect represented by the cash transfer and may have to be compensated for by other family members either taking up paid work or expanding their time in paid work. There may also be 
implications for household coping strategies with respect to shocks, if the transfers are either able to help smooth consumption or to avert damaging crisis coping mechanisms (such as selling off assets, taking children out of school and/or putting them to work), as well as preprogramme risk sharing arrangements like migration and remittances.

\section{Figure 1 Theoretical model}

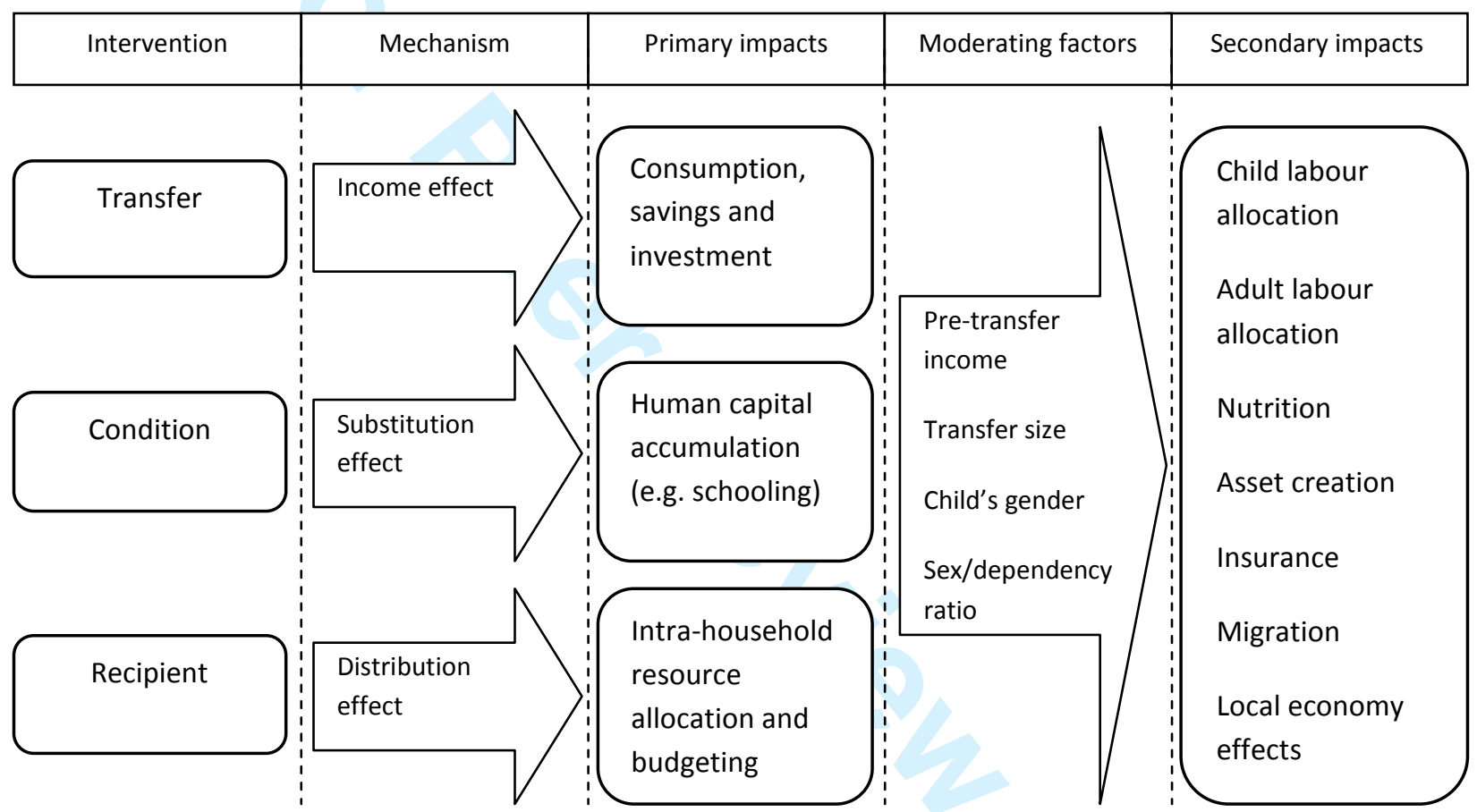

Source: authors.

Impacts may vary for several reasons. First, generosity of the benefits, which vary from 20 percent of mean household consumption in Mexico to less than 1 percent in Pakistan, is likely to affect any direct income effect and consumption smoothing for households and the local economy (Skoufias, 2007). Second, the extent, and degree of enforcement, of the conditions may be important (Baird et al., 2013). For example, Brazil's PETI programme required children aged 7 to 14 both to attend school as well as an after school programme, effectively doubling the 
school day and reducing time available for work. Third, in societies characterised by a gender division of labour (i.e. all of them), men and boys are relatively more likely to be engaged in paid work while women and girls are more likely to be found in unpaid domestic work. Consequently, we might expect an increase in girls' schooling to entail a reduction in their involvement in domestic chores, potentially adding to their mothers' workloads, over and above any time which mothers are responsible for in meeting conditionalities. An increase in boys' schooling would be more likely to entail a reduction in their involvement in paid work, with implications for household income and a possible increase in fathers' time in paid work, although the reduction in income could equally be offset by drawing non-working mothers into paid work. Thus, given that decisions about the allocation of labour by household members are unlikely to be made in isolation by individual members, CCTs may affect the allocation of adult labour within the household, both directly as a result of the income transfer and indirectly via impacts on child labour.

Finally, impacts may spillover to the wider community, reflecting an income effect due to the greater availability of money in the local economy which may in turn lead to increase in trade or inflationary pressure. It may reflect a 'demonstration effect' as behaviour change by participants is disseminated throughout the community. Or there may be a substitution effect as cash transfers crowd out previous risk sharing arrangements.

\section{Approach}

Studies eligible for the review examined the effects of CCTs on economic outcomes using quantitative impact evaluation methods including experimental design (randomised assignment) and quasi-experimental approaches (e.g. regression discontinuity and instrumental variables designs, difference-in-differences and propensity score matching methods). Systematic searches 
for relevant studies used electronic database searches including collections of scientific journals (e.g. EBSCO, the Social Science Citation Index) and institutional sources (e.g. National Bureau of Economic Research), and handsearches of academic search engines (e.g. Google Scholar), relevant academic journals, the British Library of Development Studies, and bibliographic back referencing of the reference lists of eligible studies (Figure 2). ${ }^{\text {iii }}$ After removal of duplicates, 624 unique citations were screened. Finally, after applying inclusion criteria, 46 studies were eligible for the synthesis which reported in English and Portuguese. ${ }^{\text {iv }}$

\section{Figure 2 Study search}

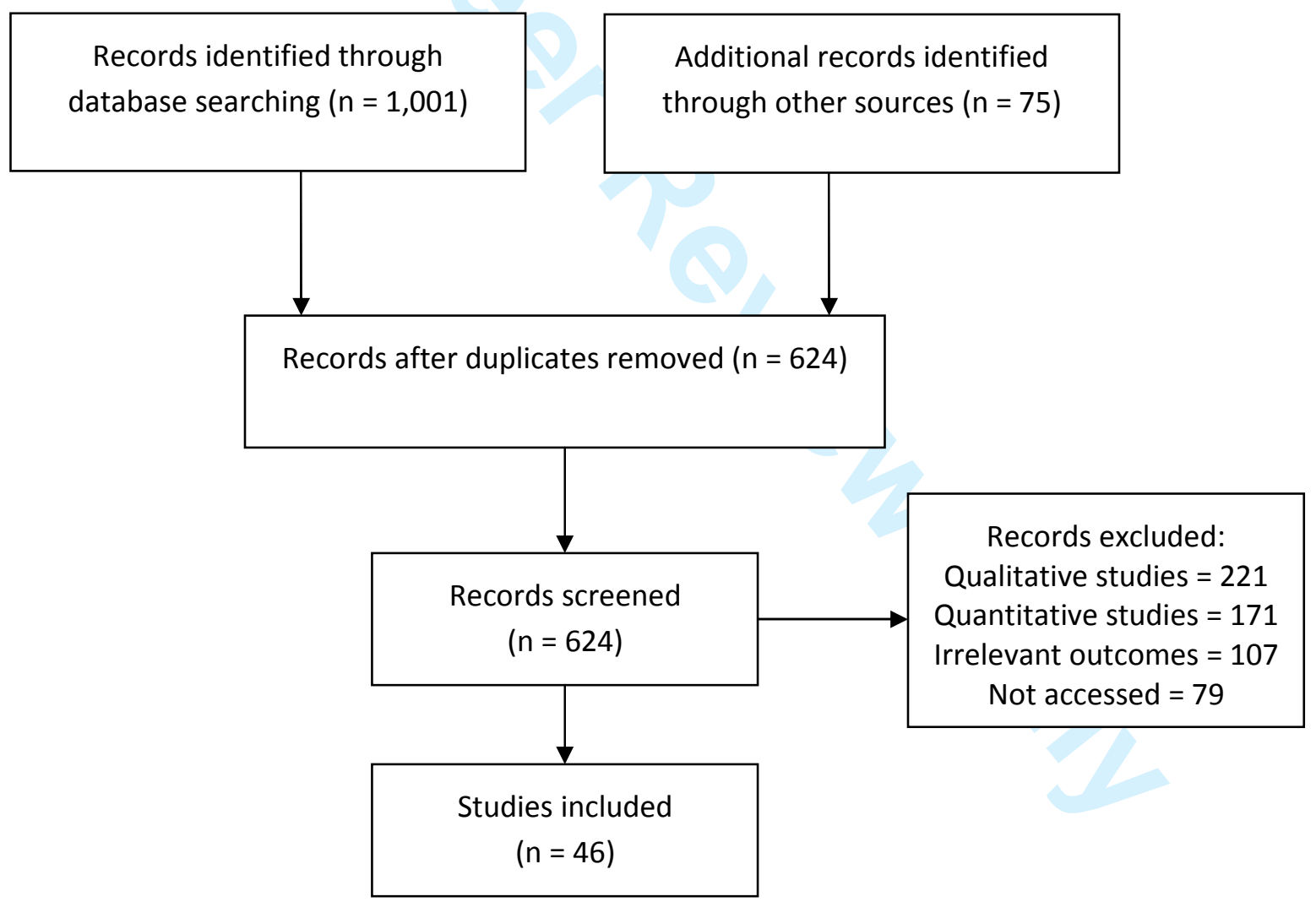

Source: adapted from Liberati et al. (2009).

Included studies provide evidence from 11 programmes in nine countries (Figure 3). ${ }^{\mathrm{v}}$ With the exception of one study from Pakistan, all are of Latin American programmes and focus their 
conditions on behaviours of pregnant mothers, infants and school age children. CCTs included in the review vary in scope and design. Some are nationwide (for example, $40 \%$ of the population are covered in Ecuador), some serve just a segment of the population (just 1\% in Cambodia) while others are small scale pilots (a few thousand in Kenya and Nicaragua). Most transfer money to the mother within the household, some providing coupons rather than cash (Costa Rica). ${ }^{\text {vi }}$ Some programmes targeted girls only (Pakistan) while others did not differentiate by gender (for example Colombia, Nicaragua).

Figure 3 Programmes included in the review

\begin{tabular}{|c|c|c|c|c|c|}
\hline Country & Programme & Coverage & Active period & $\begin{array}{l}\text { Target age } \\
\text { group* }\end{array}$ & $\begin{array}{c}\text { Number of } \\
\text { studies }\end{array}$ \\
\hline Brazil & $\begin{array}{l}\text { Bolsa Escola; Bolsa } \\
\text { Familia }\end{array}$ & $\begin{array}{l}\text { Urban and } \\
\text { Rural }\end{array}$ & 1995- & $\begin{array}{l}\text { Children aged 6- } \\
15\end{array}$ & 6 \\
\hline Brazil & $\begin{array}{l}\text { Programa de } \\
\text { Erradicacao do } \\
\text { Trabalho Infantil } \\
\text { (PETI) }\end{array}$ & $\begin{array}{l}\text { Urban and } \\
\text { Rural }\end{array}$ & 1996-2009 & $\begin{array}{l}\text { Children aged } 7- \\
14\end{array}$ & 1 \\
\hline Chile & Chile Solidario & $\begin{array}{l}\text { Urban and } \\
\text { Rural }\end{array}$ & $2002-$ & All households & 1 \\
\hline Colombia & Familias en Acción & Urban & 2000 & $\begin{array}{l}\text { School age } \\
\text { children }\end{array}$ & 3 \\
\hline Costa Rica & Superémonos & Urban & 2000 & $\begin{array}{l}\text { Children aged 6- } \\
18\end{array}$ & 1 \\
\hline Honduras & $\begin{array}{l}\text { Programa de } \\
\text { Asignación Familiar }\end{array}$ & Rural & $2000-$ & $\begin{array}{l}\text { Pregnant women } \\
\text { \& children }\end{array}$ & 2 \\
\hline
\end{tabular}




\begin{tabular}{|c|c|c|c|c|c|}
\hline & & & & under 12 & \\
\hline Mexico & $\begin{array}{l}\text { Programa de } \\
\text { Educación, Salud y } \\
\text { Alimentación } \\
\text { (PROGRESA) }\end{array}$ & Rural & $1997-2002$ & $\begin{array}{l}\text { Children aged 7- } \\
18 \text { (primary and } \\
\text { junior high } \\
\text { school only) }\end{array}$ & 16 \\
\hline Mexico & $\begin{array}{l}\text { Programa de } \\
\text { desarrollo Humano } \\
\text { Oportunidades }\end{array}$ & $\begin{array}{l}\text { Rural and } \\
\text { urban }\end{array}$ & $2002-$ & $\begin{array}{l}\text { Children aged } 7- \\
18\end{array}$ & 5 \\
\hline Nicaragua & $\begin{array}{l}\text { Atención a crisis; Red } \\
\text { de Protección Social } \\
\text { (RPS) }\end{array}$ & Rural & 2000 & $\begin{array}{l}\text { Children aged } 7- \\
13\end{array}$ & 8 \\
\hline Pakistan & $\begin{array}{l}\text { Learning and } \\
\text { Education } \\
\text { Achievement }\end{array}$ & Rural & 2004 & $\begin{array}{l}\text { Secondary } \\
\text { school age girls }\end{array}$ & 1 \\
\hline Uruguay & Plan de Equidad & $\begin{array}{l}\text { Rural and } \\
\text { urban (study } \\
\text { covers urban } \\
\text { impacts only) }\end{array}$ & $2007-$ & $\begin{array}{l}\text { Children aged 6- } \\
14\end{array}$ & 1 \\
\hline
\end{tabular}

Note: * target age group refers to education condition. Source: authors.

We use statistical meta-analysis (Borenstein et al. 2009) to pool evidence across programmes, and analysis of programme mechanisms (Pawson 2006) to synthesise evidence within individual programmes. ${ }^{\text {vii }}$ Programme effect sizes were calculated as the proportionate change in mean outcomes for beneficiaries over comparison group means, to ensure comparability across studies. The synthesis was carried out at the programme level. Where multiple studies reported on a 
programme, we calculated synthetic sample weighted average effect sizes before pooling. ${ }^{\text {vii }}$ Overall programme effects for each outcome variable were computed using inverse variance weighted random effects meta-analysis. ${ }^{\text {ix }}$

\section{Impacts on child labour}

Studies of impacts on child labour generally examined the 'extensive margin' (participation in work activities), while fewer examined the 'intensive margin' (hours worked). The effects of CCT programmes on children's labour force participation are presented in the forest plot (Figure 4), illustrating the 95 percent confidence interval (CI) associated with each programme effect size point estimate. The Figure gives a good illustration of the power of meta-analysis in pooling comparable findings across studies (Waddington et al., 2012). A simple 'vote count' of the evidence would conclude that effects on child labour are only statistically significant in half of programmes, and therefore that there is no clear impact. However, this spurious finding is because those studies estimating statistically insignificant effects are underpowered. In other words, it is likely that with sufficient sample sizes, these same studies would also have detected significant effects.

Indeed, the overall meta-analytic pooled effect, represented by the diamond, indicates that CCT programmes reduce the incidence of child labour by 7 percent on average (95\% CI: 3\%, 10\%). This finding is also consistent across programmes as indicated by the high degree of overlap in individual study confidence intervals. Indeed, nearly all of the total variance is estimated due to within study rather than the between study differences (I-squared $=13 \%$, tau-squared $=0.000$ ). 


\section{Figure 4 Effects of CCTs on children's work participation}

$$
\text { Study }
$$

ID

ES $(95 \% \mathrm{Cl})$

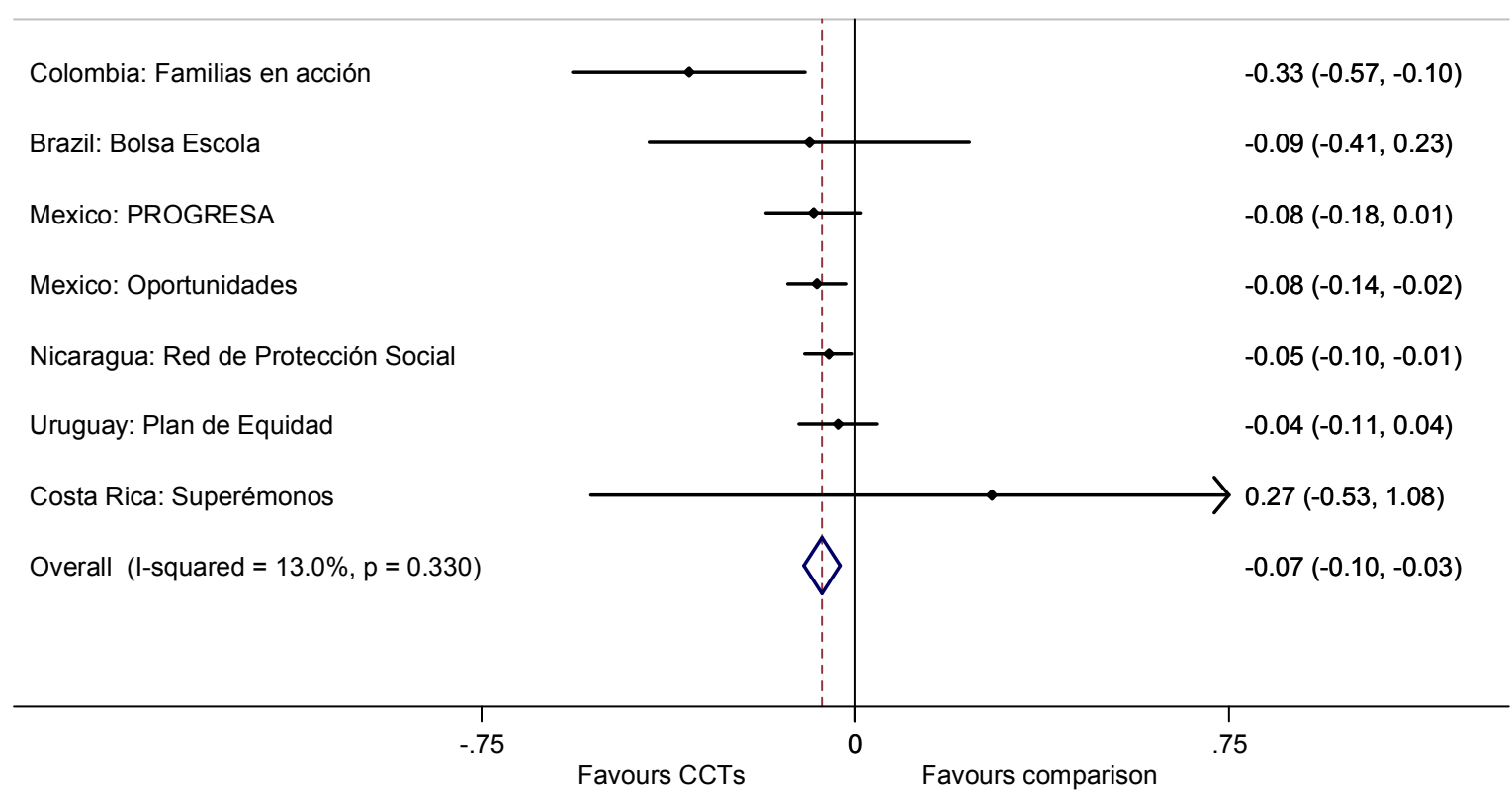

Note: ES effect size measures proportionate change.

However, these findings are moderated by gender. On average, the impact of CCTs was to reduce boys' work participation by 7 percent $(95 \%$ CI: $0 \%, 13 \%)$ but not significantly girls' work (Figure 5). However, there is substantial heterogeneity between programmes, as those in Mexico had particularly large impacts on boys' work (14 percent reduction on average). Skoufias and Parker (2001) found that the reduction in boys' work time was approximately equivalent to the increased time in schooling, suggesting education and work were competing activities. Programme participation rates, and consequently reductions in child labour also tended to be greater in rural locations, likely due to the smaller opportunity costs of school there. For 
example, in Mexico scholarships represent less than half an urban child's potential wage, but between one-half and two-thirds of a rural child's (Angelucci and de Giorgi, 2009).

Figure 5 Effects on children's work participation by gender

\begin{tabular}{|c|c|c|c|c|c|c|}
\hline \multicolumn{2}{|c|}{ Sub-group } & Pooled effect size* & \multicolumn{2}{|c|}{$95 \% \mathrm{Cl}$} & I-squared & Num obs. \\
\hline Boys & All programmes & -0.07 & -0.13 & -0.00 & $82.6 \%(p=0.00)$ & 5 \\
\hline & Mexico & -0.14 & -0.21 & -0.06 & $0 \%(p=0.72)$ & 2 \\
\hline Girls & All programmes & -0.02 & -0.05 & 0.01 & $68.9 \%(p=0.01)$ & 5 \\
\hline & Mexico & -0.05 & -0.07 & -0.02 & $0 \%(p=0.51)$ & 2 \\
\hline
\end{tabular}

Note: $*$ effect size measures proportionate change; pooled effects estimated using random effects meta-analysis. Source: authors’ calculations.

On the other hand, the lack of effect on girls' work is likely due to lower labour market participation of girls in rural areas, and concentration of girls' work in the household, which is easier to reconcile with schooling. In Nicaragua, impacts of around 10 percent reductions in labour were found for boys but not girls, partially because RPS did not provide larger stipends to girls enrolled in secondary school (Dammert, 2008). In Brazil, Bolsa Escola was found to increase the percentage of girls who combined work with school, suggesting a small significant increase in girls' labour (Cardoso and Souza, 2003). In contrast, in countries where school participation rates were already high, impacts were more likely to register in reductions in work at the intensive margin, if at all, as in Colombia (Attanasio et al., 2010) and Uruguay (Borraz and Gonzales, 2009). 
Reductions in child labour were also greater for secondary school children and poorer households. In Mexico, older rather than younger children were most likely to be working and hence experienced bigger reductions in work, particularly children of secondary school age (Schultz, 2004; Sadoulet et al., 2004; Behrman et al., 2005). Programme impacts were also moderated by income poverty in Brazil, although the amount of the transfer was too small to incentivise children to give up working entirely (Cardoso and Souza, 2003), and ethnicity in Mexico (Bando et al., 2005). In the poor rural states of North East Brazil where child labour is extremely high, PETI was more successful in reducing labour among children in part time work than those working full time, suggesting that it was the after school element of the programme that was most important in combating child labour (Yap et al., 2002).

\section{Impacts on adult labour}

In contrast, there were no consistent effects of CCTs on beneficiary parents' and guardians' labour participation across the three studies which measured this (Error! Reference source not found.). For most households, the income effect of the transfer would not be considered big enough to allow them to trade off work at extensive margins for extra leisure. However, findings were heterogeneous across programmes. The programme in Punjab, Pakistan provided evidence for a statistically significant reduction in labour market participation, as mothers in eligible households reduced their participation in paid work (Hasan, 2010). However, mothers were also found to increase their time in general household work, as the increase in girls' schooling due to CCTs meant mothers could no longer delegate household tasks to their daughters on school days. 


$$
\begin{aligned}
& \text { Study } \\
& \text { ID }
\end{aligned}
$$

ES $(95 \% \mathrm{Cl})$

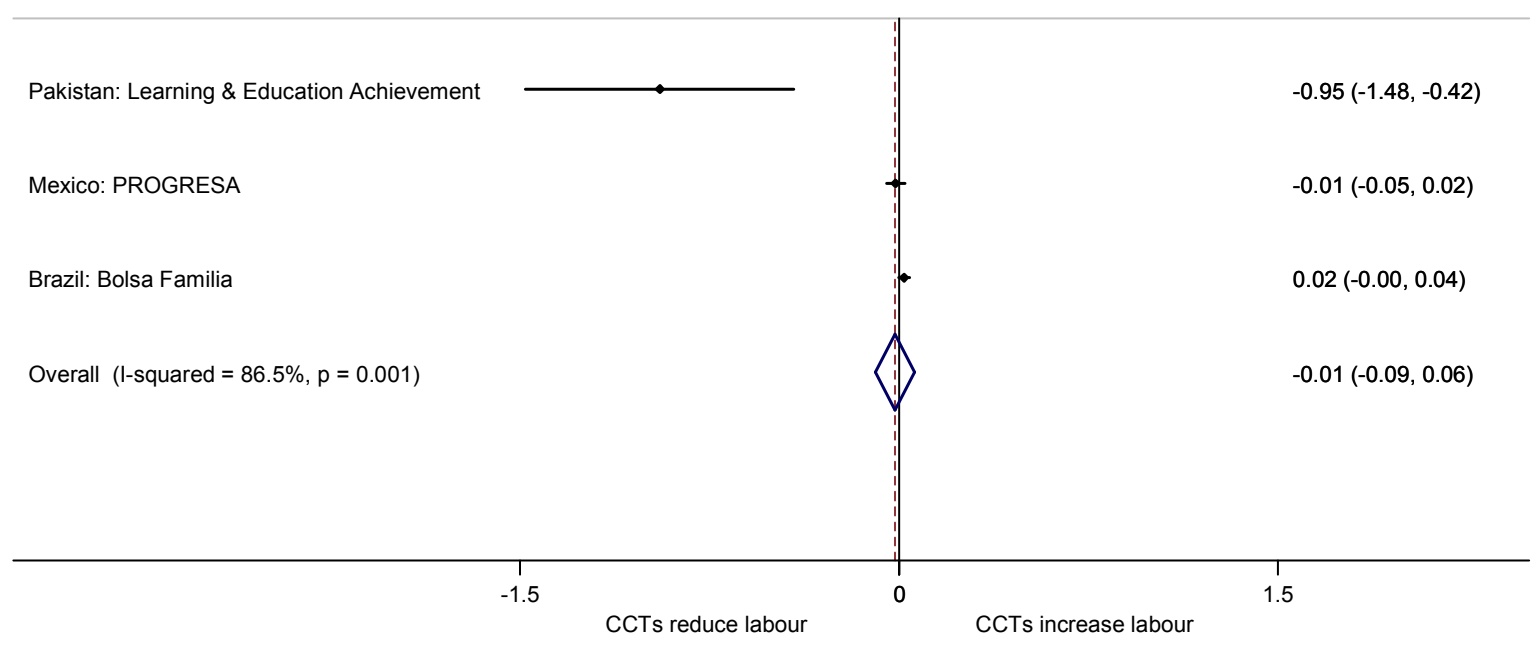

Note: ES effect size measures proportionate change.

Theory suggests that adult labour supply decisions might vary at the intensive margin due to the income effect of the transfer (disincentivising work), or the substitution effect as time is freed up from child care (incentivising work) particularly for women. Once again, impacts vary by gender. For example, in Uruguay significant reductions in working hours were found in urban areas outside Mondevideo, with men reporting a 5.1 percent and women a 17 percent reduction in working hours (Borraz and Gonzalez, 2009). Studies also suggested Bolsa Familia may have induced small reductions in mothers' hours worked by 9 to 12 percent per week (Tavares, 2008) or by 4.1 percent for women (Teixeira, 2010) in Brazil. Foguel and Barros (2008) note that impacts on women's work are likely to be inhibited by child care responsibilities. But they may 
also be due to restrictions on labour demand - for example, adults in beneficiary households in Brazil and Chile were more likely to be looking for work, particularly among lower income families (Oliveira, 2005; Galasso, 2006). In Mexico, Skoufias and di Maro (2008) found that the programme had little or no impact on adult labour force participation, irrespective of age group, but presented some evidence that the transfers were initially used to shift men out of selfemployment or unpaid work into waged work. There is little evidence of any impacts on the leisure time of either men or women.

\section{Impacts on consumption, investment and savings}

It may be reasonable to assume that CCTs have a positive effect on total consumption expenditure, because they presumably increase the disposable income of very poor households (Attanasio and Mesnard, 2005). However, disposable income may not increase by the full value of the transfer because of the associated costs, including costs of collection of transfer and income foregone from child labour. Alternatively, some of the transfer may be used to save, to invest or to pay off debts.

Results from meta-analysis indicate unambiguously that total household consumption and food consumption increased significantly as a result of the transfer in all studies (Figure 7). ${ }^{\mathrm{x}}$ There is some heterogeneity across programmes, where findings from PROGRESA (Handa et al., 2009) and Oportunidades (Todd et al., 2010) were of smaller magnitude than those from Colombia's Familias en Acción (Attanasio and Mesnard, 2005). However, the interesting finding is that within these same programmes, food and total consumption were found to increase by equivalent proportions. Other studies, for which we were not able to estimate effect sizes, also found that both total and food consumption increased as a result of the transfer including in Nicaragua 
(Maluccio, 2007; Gitter and Caldes, 2010) as well as urban (Angelucci and Attanasio, 2006) and rural Mexico (Rubalcava et al. 2009).

The findings therefore support the argument that CCTs have led to a divergence from Engel's Law, which stipulates that the share of food in household expenditure should decline with incremental income (Attanasio et al., 2009). In the case of CCTs, the targeting of women to receive the transfer appears to have changed the relative weight given to women's preferences in spending decisions and consequently incremental income being spent on nutrition rather than adult consumption items (due to the distribution effect mechanism). Further evidence indicated women were likely to use cash at their disposal very differently from men in their households. In Mexico, transfers to women in couple headed households resulted in higher quality nutritional intake, purchases of children's clothing and female associated forms of investment, but not in households headed by a single parent, whether male or female (Rubalcava et al. 2009).

\section{Figure 7 Effects of CCTs on household consumption}

\begin{tabular}{|c|c|c|c|c|c|}
\hline Programme & Sub group & Effect size* & $95 \% \mathrm{Cl}$ & & Num. studies \\
\hline \multirow[t]{2}{*}{ PROGRESA } & Total consumption & 0.026 & 0.008 & 0.044 & 1 \\
\hline & Food consumption & 0.026 & 0.006 & 0.046 & 1 \\
\hline Oportunidades & Food consumption & 0.041 & 0.005 & 0.077 & 1 \\
\hline \multirow[t]{2}{*}{ Familias en Acción } & Total consumption & 0.160 & 0.048 & 0.271 & 1 \\
\hline & Food consumption & 0.192 & 0.075 & 0.310 & 1 \\
\hline RPS & Total consumption & 0.178 & 0.043 & 0.313 & 1 \\
\hline
\end{tabular}


Note: Effect size measures proportionate change. Source: authors' calculations.

The proportion of the transfer income consumed was estimated between 80 and 90 percent in Brazil (Resende and Oliveira, 2008), Colombia (Angelucci and Attanasio, 2006) and Mexico (Gertler et al. 2006). In Mexico, the residual income was found to increase household savings (Rubalcava et al., 2009), as well as investment in productive activities and assets (Davis et al., 2004; Angelucci and de Giorgi, 2009; Todd et al., 2010). Indeed, the return on each peso invested was over 15 percent, which is substantially higher than the average annual real interest rate in the economy (Gertler et al., 2006). The evidence therefore suggests CCTs relaxed liquidity constraints in Mexico. In contrast, there was no evidence that RPS led to increased investment in productive assets or off-farm microenterprise activity by participating households in rural Nicaragua (Maluccio, 2010) or in productive investments for coffee growers in Honduras (Coady et al., 2003).

\section{Risk sharing and community level impacts}

Studies found that CCTs enabled households to withstand shocks and avoid negative coping strategies. In Mexico (de Janvry et al., 2006) and in Honduras (Coady et al., 2003), the programmes mitigated the likelihood of reductions in school enrolment in response to shocks such as illness or unemployment of a household head. In Nicaragua, the programme enabled consumption smoothing for producers (Maluccio and Flores, 2005; Maluccio, 2007). There was no evidence that CCTs crowded out pre-existing forms of risk sharing such as remittances in Mexico (Skoufias, 2007), Honduras and Nicaragua (Nielsen and Olinto, 2007; Hernandez et al., 2009). 
Relatedly, there was no consistent evidence of effects of CCTs on migration in Mexico. ${ }^{\mathrm{xi}}$ One study suggested a short term rise in migration to the USA during the first few months of PROGRESA's implementation (Angelucci, 2004) - possibly due to households' anticipation of transfers as no subsidies had yet taken place. Another found migration fell several years into implementation (Stecklov et al., 2005) including a reduction among male youth of 6 percent. A final study another suggested increased male migration to the north of the country (Azuara, 2009) which Schultz (2004) characterises as an economically desirable outcome since it would move the young out of regions of extreme poverty and into non-agricultural sectors of the economy, which in turn would in turn boost long term growth. However, PROGRESA also appears to have done little to stem the flow of female migration to domestic, mainly urban, destinations (ibid.).

A number of papers argue for the need to broaden the scope of the evaluations to capture spillovers and general equilibrium effects (Fafchamps and Lund, 2003; Skoufias and di Maro, 2008; Angelucci and de Giorgi, 2009; Handa et al., 2001, 2009). CCTs were associated with a 4 percentage point lower rate of increase in village level poverty incidence, depth and severity in Mexico (Handa et al., 2009), the size of the impact increasing over time (Skoufias and di Maro, 2008). CCTs were also associated with an increase in food consumption among ineligible households, partly because of greater availability of resources within the village but also because resources were shifted away from recipient households (Angelucci and de Giorgi, 2009). There was possible evidence of positive spillover effects on non-beneficiary secondary school attendance and attainment (Gignoux, 2009), as well as health care behaviour and fewer sick days among non-beneficiaries, an effect which also increased over time (Handa et al., 2001). 
There was no evidence of inflationary impacts of transfers in Mexico, possibly because beneficiaries spent their money outside their own communities (for instance in the municipal capital) especially when they had to travel outside their communities to receive their transfers (Handa et al., 2009).

\section{Conclusion}

The evidence indicates that conditional cash transfers lead to lower rates of child labour on average, particularly for boys. This is consistent with previous systematic reviews which showed CCTs improve school enrolment and attendance (Baird et al. 2013). Effects on girls' labour were greater where programmes specifically targeted them. Impacts on household consumption including consumption smoothing - were found to be unambiguously positive. However, the results do not suggest there are consistent changes in adult labour decisions at extensive or intensive margins. Thus, while the income effect seems to be strong enough to reduce child labour and increase consumption, it is not sufficient to lead to a reduction in adult labour force participation. There was also some evidence that transfers raised savings and investment, although only for 10 to 20 percent of the size of the transfer on average. Very few studies have measured spillover and general equilibrium effects of transfers.

The searches for this review were completed in 2010. An update is needed to capture relevant studies which have been produced more recently. In particular, as CCT programmes have now been in existence for two decades and the first cohorts of beneficiaries reach adulthood, we are hopeful that more primary evidence on long term economic outcomes including labour market outcomes and community level poverty aggregates will be available. Furthermore, an update could usefully make use of the large amount of available qualitative evidence to articulate the mechanisms and contextual factors which explain differences between and within programmes. 


\section{References}

Angelucci, M. (2004) Aid and Migration: An Analysis of the Impact of Progresa on the Timing and Size of Labour Migration. IZA DP No. 1187.

Angelucci, M. and O. Attanasio (2006) Oportunidades: Programme Effect on Consumption, Low Participation, and Methodological Issues University of Arizona Economics Working Paper, WP$06-13$.

Angelucci, M. and G. De Giorgi (2009) 'Indirect Effects of an Aid Programme: How Do Cash Transfers Affect Ineligibles' Consumption?' The American Economic Review, 99 (1), 486.

Attanasio, O. and A. Mesnard (2005) 'The impact of a conditional cash transfer programme on consumption in Colombia.' Fiscal Studies, 27 (4), 421-442.

Attanasio, O., E. Battistin and A. Mesnard (2009) Food and Cash Transfers: Evidence from Colombia. IFS, Working Paper W09/15.

Attanasio, O., E. Fitzsimons, A. Gomez, M. Gutierrez, C. Meghir and A. Mesnard (2010) 'Children's Schooling and Work in the Presence of a Conditional Cash Transfer Programme in Rural Colombia.' Economic Development and Cultural Change, 58 (2), 181-210.

Azuara, O. (2009) Does Poverty Alleviation Increase Migration? Evidence from Mexico. University Library of Munich, Germany. (RDD)

Bando, G. R., L.F. Lopez-Calva and H.A. Patrinos (2005) Child Labour, School Attendence, and Indigenous Households: Evidence from Mexico. World Bank Policy Research Working Paper 3487, January. 
Behrman, J.R., S. Parker and P.E. Todd (2005) Long-Term Impacts of the Oportunidades Conditional Cash Transfer Programme on Rural Youth in Mexico. Ibero-America Institute for Economic Research, Discussion Paper Nr.122.

Baird, S., B. Ozler, F. Ferreira and M. Woolcock (2013) 'Effectiveness and cost effectiveness of conditional cash transfers versus unconditional cash transfers in improving education.' Campbell systematic reviews. Available from: http://campbellcollabouration.org/lib/project/218/ [Accessed 15 September 2014].

Barrientos, A. and D. Hulme (2009) 'Social Protection for the Poor and Poorest in Developing Countries: Reflections on a Quiet Revolution.' Oxford Development Studies, 37 (4), 439-456

Borenstein, M., L. Hedges, J. Higgins and H. Rothstein (2009) Introduction to Meta-Analysis. John Wiley \& Sons, Ltd.

Borraz, F. and N. González (2009) Impact of the Uruguayan Conditional Cash Transfer Programme. Cuadernos de Economía (Latin American Journal of Economics), 46 (134), 243271.

Cardoso, E. and A.P. Souza (2003) The Impact of Cash Transfers on Child Labour and School Attendance in Brazil, Vanderbilt University, Working Paper \# 04-W07, April.

Coady, D., P. Olinto, and N. Caldes (2003) Coping with the Coffee Crisis in Central America: The Role of Social Safety Nets in Honduras. IFPRI research report.

Dammert, A. (2009) 'Heterogeneous Impacts of Conditional Cash Transfers: Evidence from Nicaragua.' Economic Development and Cultural Change, 58 (1), 53. 
De Janvry, A, F. Finan, E. Sadoulet, R. Vakis (2006) 'Can conditional cash transfer programmes serve as safety nets in keeping children at school and from working when exposed to shocks?' Journal of Development Economics, 79 (2), 349.

Dev, M. (1995) 'India's (Maharashtra) employment guarantee scheme: lessons from long experience', in: von Braun, J. (ed.) Employment for poverty reduction and food security, International Food Policy Research Institute, Washington, D.C.

Fiszbein, A. and N. Schady (2009) Conditional cash transfers: Reducing present and future poverty. Policy Research Report, World Bank, Washington, D.C.

Foguel, M.N. and R.P. Barros, (2009) The Effects of Conditional Cash Transfer Programmes on Adult Labour Supply: An Empirical Analysis Using a Time-Series-Cross-Section Sample of Brazilian Municipalities. Foz do Iguaçu, Brazil. XXXVII Encontro Nacional De Economia.

Gaarder, M., A. Glassman and J. Todd (2010) 'Conditional cash transfers and health: unpacking the causal chain.' Journal of Development Effectiveness, 2 (1).

Galasso, E. (2006) "With their effort and one opportunity": Alleviating extreme poverty in Chile. IADB Working Paper.

Gertler, P., S. Martinez, and M. Rubio-Codina (2006) Investing cash transfers to raise long term living standards. The World Bank.

Gignoux, J. (2009) Spillovers of Conditional Cash Transfers across Localities: evidence from Progresa. Labouratoire d'Economie Appliquee, INRA.

Gitter, S.R. and N. Caldés (2010) Crisis, Food Security, and Conditional Cash Transfers in Nicaragua. Towson University, Department of Economics, Working Paper No. 2010-07. 
Handa, S., A. Peterman, B. Davis and M. Stampini (2009) 'Opening Up Pandora's Box: The Effect of Gender Targeting and Conditionality on Household Spending Behaviour in Mexico's Progresa Programme.' World Development, 37 (6), 1129.

Handa, S., M.C., Huerta, R. Perez and B. Straffon (2001) Poverty, Inequality, And Spillover In Mexico's Education, Health, And Nutrition Programme. IFPRI, Fend Discussion Paper No. 101, March.

Hasan, A. (2010) Time Allocation in Rural Households: The Indirect Effects of Conditional Cash Transfer Programs. World Bank Policy Research Working Paper No. 5256.

Hernandez, E., et al. (2009) Impact of Conditional Cash Transfers and Remittances on Credit Market Outcomes in Rural Nicaragua. Agricultural and Applied Economics Association. (IV)

Kabeer, N. (2009) Scoping study on social protection: evidence on impacts and directions for future research. Research and Evidence Division, Department for International Development, London.

Kabeer, N., C. Piza and L. Taylor (2012) What are the economic impacts of conditional cash transfer programmes? A systematic review of the evidence. Technical report. EPPI-centre, Social Science Research Unit, Institute of Education, University of London, London.

Lagarde, M., A. Haines and N. Palmer (2009) 'The impact of conditional cash transfers on health outcomes and use of health services in low and middle Income countries.' Cochrane database of systematic reviews (4AR CD008137).

Leroy, J., M. Ruel and E. Verhofstadt (2009) 'The impact of conditional cash transfer programmes on child nutrition: a review of evidence using a programme theory framework.' Journal of Development Effectiveness, 1 (2), 103-129. 
Liberati, A., D. Altman, J. Tetzlaff, C. Mulrow, P. Gøtzsche, J. Ioannidis, M. Clarke, P. Devereaux, J. Kleijnen and D. Moher (2009) 'The PRISMA statement for reporting systematic reviews and meta-analyses of studies that evaluate healthcare interventions: explanation and elabouration.' British Medical Journal, BMJ 2009;339:b2700

Lin, J. and J. Pumaphi (2009) 'Foreword' in Fizbein and Schady, cited above.

Maluccio, J. (2010) 'The Impact of Conditional Cash Transfers on Consumption and Investment in Nicaragua.' Journal of Development Studies, 46 (1), 14.

Maluccio, J.A and R. Flores (2005) Impact Evaluation of A Conditional Cash Transfer Programme: The Nicaraguan Red De Protección Social. IFPRI, Research Report.

Maluccio, J.A. (2005) Coping with the coffee crisis in Central America: The Role of the Nicaraguan Red de Proteccion Social. International Food Policy Research Institute (IFPRI).

Nielsen, M.E. and P. Olinto (2007) Do Conditional Cash Transfers Crowd Out Private Transfers? Evidence from Randomized Trials in Honduras and Nicaragua. Working Paper, April.

Manley, J., S. Gitter and V. Slavchevska (2012) How effective are cash transfer programmes at improving nutritional status? A rapid evidence assessment of programmes' effects on anthropometric outcomes. EPPI-Centre, Social Science Research Unit, Institute of Education, University of London.

Oliveira, A.M.H.C de. (2005) An Evaluation of the Bolsa Familia Programme in Brazil: Expenditures, Education and Labour Outcomes. CEDEPLAR Working Paper.

Pawson, R. (2006) Evidence-based policy. A realist perspective. Sage Publications, London.

Ravallion, M. and Wodon Q. (2000) 'Does Child Labor Displace Schooling? Evidence on Behavioral Responses to an Enrollment Subsidy.' Economic Journal, 110 (462), 158-75. 
Resende, A.C.C. and A.M.H.C. Oliveira (2008) 'Avaliando Resultados de um Programa de Transferência de Renda: o Impacto do Bolsa-Escola sobre os Gastos das Famílias Brasileiras.' Estudos Economicos, São Paulo, 38 (2), 235-265.

Rubalcava, L., G. Teruel, and D. Thomas (2009) 'Investments, Time Preferences, and Public Transfers Paid to Women.' Economic Development and Cultural Change, 57, 507-538.

Sadoulet, E. F. Finan, A. De Janvry and R.Vakis (2004) Can conditional cash transfer programmes improve social risk management? Lesson for education and child labour outcomes. IBRD. SP discussion papers, No. 0420.

Schultz, P.T. (2004) 'School subsidies for the poor: evaluating the Mexican Progresa poverty programme.' Journal of Development Economics, 74, 199-250.

Skoufias, E., and Gonzalez-Cossio, T. 2008. The Impacts of Cash and In-Kind Transfers on Consumption and Labour Supply Experimental Evidence from Rural Mexico. World Bank, Policy Research Working Paper No. 4778, November.

Skoufias, E. and S.W. Parker (2001) 'Conditional cash transfers and their impact on child work and schooling: Evidence from the Progresa Programme in Mexico.' Economia, Fall, 45-96.

Skoufias, E. \& V. Di Maro (2008) 'Conditional Cash Transfers, Adult Work Incentives, and Poverty.' Journal of Development Studies, 44, 935 - 960.

Skoufias, E. (2007) 'Poverty alleviation and consumption insurance: Evidence from PROGRESA in Mexico.' Journal of Socio-Economics, 36 (4), 630.

Stecklov et al. (2005) 'Do conditional cash transfers influence migration? A study using experimental data from the Mexican Progresa programme.’ Demography, 42, 769. 
Tavares, P.A. (2008) Efeito do Programa Bolsa Família sobre a oferta de trabalho das mães. ABEP, Brazil.

Teixeira, C.G. (2010) A Heterogeneity Analysis Of The Bolsa Família Programme Effect On Men And Women's Work Supply. International Policy Centre for Inclusive Growth-UNDP, Working Paper No.61, March.

Todd, J., P. Winters, and T. Hertz (2010) 'Conditional Cash Transfers and Agricultural Production: Lessons from the Oportunidades Experience in Mexico.' The Journal of Development Studies, 46 (1) 39-67.

Waddington, H., H. White, B. Snilstveit, J. Hombrados, M. Vojtkova, P. Davies, A. Bhavsar, J. Eyers, T. Koehlmoos, M. Petticrew, J. Valentine and P. Tugwell (2012) 'How to do a good systematic review of effects in international development: a tool kit.' Journal of Development Effectiveness, 4 (3), 359-387, DOI: 10.1080/19439342.2012.711765.

Yap, Y-T., G. Sedlacek and P.F. Orazen (2002) Limiting Child Labour Through BehaviourBased Income Transfers: An Experimental Evaluation of the PETI Programme in Rural Brazil. Working Paper, June.

Yoong, J., L. Rabinovich and S. Diepeveen (2012) The impact of economic resource transfers to women versus men: a systematic review. Technical Report. London: EPPI-Centre, Social Science Research Unit, Institute of Education, University of London. 
${ }^{i}$ Although now a CCT programme, the Bangladesh programme originally provided conditional food (rice) transfers. The impact evaluation of the Bangladesh Food for Education Programme is not eligible for this review which is limited to cash transfers (Ravallion and Wodon, 2000).

ii The systematic review technical report, including the complete list of included studies, is downloadable from the EPPI-centre (Kabeer et al., 2012).

iii Searches were conducted in July 2010 by two researchers working independently without date restrictions. The search terms were entered in English, but the search also located studies published in Spanish and Portuguese whose abstracts had been translated.

${ }^{\text {iv }}$ Purely qualitative papers were excluded, as well as ineligible quantitative papers (e.g. general equilibrium model studies and non-experimental regression studies) and studies that were inaccessible, either because they were listed in databases but inaccurately cited and untraceable through other means, or because they existed only in hard copy in libraries in other countries, including masters and doctoral theses. No studies were excluded on language grounds. Spanish language papers frequently occurred in the initial list, but were dropped as the process advanced, as they were generally working papers leading to a refereed article written in English.

${ }^{\mathrm{v}}$ Mexico's Oportunidades extended PROGRESA to urban areas and older beneficiaries, so these are considered as independent programmes for the purposes of this review. Atención a Crisis was a pilot within the larger Red de Protección Social (RPS) in Nicaragua, and took its target population from within the RPS, so studies on these are therefore referred to synonymously in the review. The three Brazilian programmes (Bolsa Escola, Bolsa Familia and PETI) all began as separate programmes with different targeting criteria. However, Bolsa Escola and Bolsa Familia were merged in 2003 and since then have shared a distribution mechanism and various conditionalities; the papers dealing with these two programmes all date from after their merging, and are therefore listed together. PETI was folded into Bolsa Familia later, in 2009. The only paper included in this review that deals with PETI exclusively is Yap et al. (2002), and the analysis therefore distinguishes it as a separate programme.

vi The impact evaluation of Mexico's food transfer programme, Programa Apoyo Alimentario (PAL), compared the effects of food versus cash transfers (Skoufias and Gonzalez-Cossio, 2008). However, PAL is an unconditional cash transfer programme and hence ineligible for the review.

${ }_{\text {vii }}$ More detailed findings are presented in the full technical report (Kabeer et al., 2012).

${ }^{\text {viii }}$ Following Borenstein et al. (2009, p.226) the standard error (SE) of two effect sizes $\beta_{1}$ and $\beta_{2}$ was calculated as $S E=\left[\frac{1}{4}\left(\operatorname{Var}\left(\beta_{1}\right)+\operatorname{Var}\left(\beta_{2}\right)+2 \operatorname{Cov}\left(\beta_{1}, \beta_{2}\right)\right)\right]^{0.5}$, assuming that the covariance between effect sizes was equal to 0.5 .

${ }^{\text {ix }}$ All figures and meta-analyses were computed using the command metan in Stata (Stata Corp., College Station, TX).

${ }^{x}$ We opted not to estimate pooled effects across programmes using meta-analysis in this case, due to the high degree of heterogeneity between Mexico and Colombia studies as well as statistical significance of all individual study estimates.

${ }^{x i}$ All evidence on migration and community-wide effects is from Mexico. 